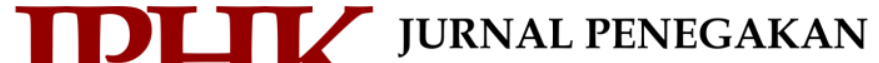 HUKUM DAN KEADILAN}

Vol. 2 No. 2, September 2021, Hal. 117-129

P-ISSN: 2746-0967, E-ISSN: 2721-656X
Gedung Pascasarjana Kampus Terpadu UMY Jalan Brawijaya, Tamantirto, Kasihan, Bantul, Yogyakarta 55183

Telepon : (0274) 387656 Ext. 346

Email : jphk@umy.ac.id

\title{
Implementasi Ratifikasi Agreement on Trade Related Aspects of Intellectual Property Right (Trips Agremeent) terhadap Politik Hukum di Indonesia
}

\section{Erika Vivin Setyoningsih}

Kementerian Hukum dan Hak Asasi Manusia Republik Indonesia, Indonesia

E-mail: erikavivinsetyoningsih@gmail.com

\author{
INFO ARTIKEL \\ Perjalanan Artikel: \\ Artikel Dikirimkan oleh \\ penulis: 11-05-21 \\ Artikel Direview: 22-06-21 \\ Artikel Direvisi: 09-11-21 \\ Artikel Diterima atau \\ Dipublikasikan: 16-11-21 \\ DOI: \\ 10.18196/jphk.v2i2.11749
}

\begin{abstract}
ABSTRAK
Penelitian Yuridis normatif ini dilakukan untuk mengkaji ratifikasi perjanjian internasional terkait Hak Kekayaan Intelektual (HAKI) apakah sudah sesuai dengan kondisi politik hukum di Indonesia. HAKI merupakan hak ekslusif yang tumbuh dari hasil olah pikir rasio manusia yang diekspresikan kepada khalayak umum dalam berbagai bentuk barang dan jasa, yang mengandung manfaat dan berguna dalam menunjang kebutuhan hidup umat manusia, serta mempunyai nilai ekonomi dan nilai moral. Indonesia adalah negara yang menandatangani kesepakatan terhadap pembentukan organisasi perdagangan dunia (World Trade Organization). Perjanjian yang ditandatangai oleh Indonesia yang terkait dengan aspek perdagangan internasional yang berhubungan dengan HAKI adalah Agreement on Trade Related Aspect Of Intellectual Property Right (Trips Agreement), yang telah diratifikasi oleh Pemerintah Indonesia ke dalam Undang-Undang No. 7 Tahun 1994 tentang Pengesahan Agreement Establishing The World Trade Organization (Persetujuan Pembentukan Organisasi Perdagangan Dunia). Penelitian menemukan fakta bahwa ratifikasi perjanjian internasional ini menimbulkan dampak yang dapat mempengaruhi iklim politik hukum di Indonesia. Seharusnya kesepakatan dalam ratifikasi TRIPs Agreement ke dalam hukum nasional disesuaikan dengan politik hukum bangsa Indonesia, sehingga implementasi ratifikasi perjanjian internasional HAKI terhadap politik hukum di Indonesia berjalan dalam koridor yang sesuai.
\end{abstract}

Kata Kunci: : HAKI, politik hukum, TRIPs Agreement, World Trade Organization

\section{Pendahuluan}

Hak Kekayaan Intelektual (selanjutnya dituliskan dengan HAKI) memiliki peranan penting dalam kehidupan berbisnis. Hal ini karena HAKI menunjukkan suatu identitas terhadap pemegang haknya dan Negara hadir untuk melindungi setiap hasil olah pikir rasio manusia. HAKI dalam implementasinya bukan hanya urusan lokal suatu Negara melainkan urusan global dari berbagai Negara yang turut dalam meratifikasi TRIPs Agremeent. Sehingga urusan mengenai HAKI bersifat secara global. 
Dalam meratifikasi TRIPs Agreement, secara langsung Indonesia setuju terhadap kesepakatan berbagai Negara anggota yang secara hukum berbeda iklim politik hukum antar Negara. Hasil ratifikasi TRIPs Agreement berupa kesepakatan umum yang berlaku secara global diantara Negara anggotanya. Hal tersebut dapat menyebabkan ketidaksesuaian politik hukum di Indonesia dengan di dunia global.

Penting bagi Indonesia untuk menyesuaikan iklim politik hukum dalam menerapkan TRIPS Agreement yang tidak bertentangan dengan landasan yuridis, filosofis dan sosiologis Negara Indonesia. Konsekuensi hukum ratifikasi tersebut adalah secara substansif tunduk terhadap hukum nasional sebagai lex specialist, sedangkan TRIPs Agreement berlaku sebagai lex generalis.

Perjanjian internasional tentang HAKI 1 diratifikasi oleh Indonesia melalui Undang-undang Nomor 7 Tahun 1994 tentang Pengesahan Agreement Establishing the World Trade Organization (Persetujuan Pembentukan Organisasi Perdagangan Dunia). Ratifikasi dimaksudkan untuk memberlakukan ketentuan TRIPs Agreement ke dalam hukum nasional. Perbedaan iklim politik hukum di dunia Internasional dengan di Indonesia akan mempengaruhi berlakunya ketentuan dalam TRIPs. Dampak lain dari ratifikasi ini adalah untuk menekan angka pelanggaran HAKI di Indonesia.

Pelanggaran dalam bidang HAKI di Indonesia masih dinominasi kasus hak cipta. Penggunaan kekayaan Intelektual oleh bukan orang yang memiliki adalah suatu pelanggaran. Saat ini pelanggaran HAKI (HKI) menjadi problem di berbagai belahan dunia termasuk Indonesia. Dampak terhadap pelanggaran HKI adalah kerugian ekonomi nasional. Pada tahun 2011 hingga 2016, perkara HAKI terdokumentasi ada 616 perkara dengan perincian sebagai berikut: perkara merk sebanyak 274, perkara desain industri 16, perkara paten 7 dan perkara rahasia dagang 3 . Sudah saatnya perlindungan Kekayaan Intelektual diupayakan dalam lingkup Preemtif dan Preventif saja, dan juga tidak dalam bentuk upaya represif melalui penegakan hukum Kekayaan Intelektual. ${ }^{1}$

Seiring dengan berkembangnya kekayaan intelektual, terlebih sejak ditandatanganinya TRIPs Agreement, yang menjadi kesepakatan internasional bidang HAKI. TRIPs Agreement merupakan kesepakatan di bawah organisasi perdagangan dunia yakni WTO (World Trade Organization) dengan tujuan menyelaraskan sistem HAKI terhadap semua anggota WTO. HAKI merupakan salah satu isu perdagangan yang dibahas dalam perundingan pada Putaran Uruguay. Sejak 1986 Putaran Uruguay merupakan perundingan perdagangan multilateral dalam kerangka General Agreement on Tarriff and Trade/ GATT, dengan kesepakatan penandatanganan atau Contracting Parties GATT. ${ }^{2}$

\footnotetext{
1 Nirwani, N. (2018). Seminar Pelanggaran Kekayaan Intelektual. Dikutip 16 Juli 2021, dari situs web Kantor Wilayah Sulawesi Utara Kementerian Hukum dan HAM https://sulut.kemenkumham.go.id/berita-kanwil/berita-utama/2609-seminar-pelanggaran-kekayaanintelektual.

2 Hanafi, I. H. (2011). Perdagangan Internasional Pasca Putaran Uruguay dan Dampaknya di Indonesia. Jurnal Sasi, 17(4), hlm. 2.
} 
Pada prinsipnya World Trade Organization (WTO) merupakan suatu alat guna meningkatkan terjadinya suatu perdagangan bebas yang tertib dan adil di dunia. WTO dalam menjalankan tugasnya, memberlakukan beberapa prinsip yang menjadi pilarpilar World Trade Organization (WTO). Liberlisassi perdagangan yang ditetapkan melalui aturan WTO mendorong Negara-negara anggotanya mengikuti aturan WTO tersebut. ${ }^{3}$

Keikutsertaan Indonesia dalam meratifikasi dan menyepakati perjanjian TRIPs, secara otomatis Indonesia mempunyai konsekuensi untuk melaksanakan ketentuan perjanjian dalam TRIPs. Besar harapan setelah adanya ratifikasi perjanjian TRIPs, Indonesia memperoleh manfaat serta dapat mengambil berbagai aspek HAKI yang sesuai dengan hukum nasional. Perjanjian internasional tersebut kemudian diadopsi ke dalam hukum nasional.

Disisi lain, akibat dari ratifikasi tersebut akan menimbulkan berbagai dampak yang akan mempengaruhi iklim politik hukum dalam negeri. Perlindungan terhadap kepentingan nasional menjadi tantangan yang harus dihadapi bangsa Indonesia. Sejak bergabung dengan ikut dalam perundingan TRIPs, dalam arti Indonesia sepakat terhadap ketentuan-ketentuan yang berlaku, yang tidak semua ketentuannya selaras dengan iklim budaya bangsa Indonesia. Bangsa kita yang bersifat sosialis tidak bersifat individualis menjadi tantangan sendiri dalam menerapkan agreement yang telah disepakati. Dengan demikian dari rangkaian uraian yang sudah dijelaskan tersebut, penulis mengambil permasalahan yaitu Bagaimana implementasi dari ratifikasi TRIPS Agreement terhadap politik hukum di Indonesia?

\section{Metodologi}

Penelitian hukum yuridis normatif dipergunakan untuk membahas doktrindoktrin atau asas-asas dalam ilmu hukum, ${ }^{4}$ dan mengkaji implementasi ratifikasi perjanjian internasional yang berupa TRIPs Agreement untuk diadopsi ke dalam hukum nasional ditinjau dari sisi politik hukum.

Metode pendekatan perundang-undangan dipergunakan untuk mengkaji produk hukum yang dikeluarkan memiliki kekuatan mengikat. Data dalam penelitian ini berupa data sekunder dalam bentuk bahan hukum primer, sekunder dan tersier. Metode analisis deskriptif dilakukan untuk memberikan gambaran serta pemaparan terhadap hasil akhir penelitian tentang implementasi ratifikasi TRIPs Agreement sudah sesuai dengan politik hukum bangsa Indonesia.

\footnotetext{
${ }^{3}$ Jamilus. (2017). Analisis Fungsi dan Manfaat WTO bagi Negara Berkembang (Khususnya Indonesia). Jurnal Ilmiah Kebijakan Hukum, 11(2), hlm. 206.

4 Ali, Z. (2009). Metode penelitian hukum. Jakarta: Sinar Grafika, hlm. 24
} 


\section{Analisis dan Hasil}

\subsection{Pengertian TRIPs Agreement}

TRIPS Agreement bukan merupakan ketentuan khusus yang mengatur tentang HAKI. TRIPS Agreement merupakan perjanjian Internasional yang menjadi bagian WTO (World Trade Organization) serta ditanda tangani oleh beberapa Negara anggota dan mewajibkan Negara anggota membuat ketentuan atau aturan salah satunya tentang HAKI. Keikutsertaan Indonesia dalam anggota WTO, membawa konsekuensi untuk melakukan penyesuaian penyusunan peraturan perundang-undangan nasional tentang HAKI dengan mendasarkan pada standar tentang pengaturan dan perlindungan HAKI yang telah ditentukan oleh TRIPs Agreement.

Nurul Barizah ${ }^{5}$ mendeskripsikan TRIPS sebagai berikut: "The TRIPS Agreement is a pivotal legal document dealing with Intellectual Property Rights. This Agreement is the most significant, influential, and comprehensive agreement on Intellectual Property Rights as one of the pillars of the WTO global trade regime. It deals with listed ranges of Intellectual Property Rights, establishing minimum universal standards of protection, requiring effective enforcement measures and establishing a dispute settlement mechanism. Due to its significant outreach, scholars describe this agreement as involving a radical change, a 'conceptual leap', in the history of Intellectual Property Rights, including revolutionising international Intellectual Property Laws".

Artinya bahwa, TRIPS Agreement sebagai salah satu pilar rezim perdagangan WTO merupakan dokumen hukum yang penting, paling berpengaruh dan komprehensif. TRIPS Agreement merupakan suatu perjanjian yang menetapkan standard dalam perlindungan HAKI dan mewajibkan setiap negara anggota mengimplementasikan ke dalam peraturan perundang-undangan yang bersifat nasional. 6

TRIPS Agreement terdiri dari 7 bagian, bagian pertama tentang General Provisions and Basic Principles (Ketentuan Umum dan Prinsip Dasar). Di dalam ketentuan dasar ini memuat lingkup sifat dan kewajiban Negara anggota, konvensi kekayaan intelektual, perlakuan nasional, perlakuan terhadap bangsa dari Negara anggota, perjanjian multilateral tentang akuisisi atau pemeliharaan/perlindungan, penyelesaian sengketa, tujuan dan prinsip.

Bagian kedua tentang Standards Concerning The Availability, Scope And Use Of Intellectual Property Rights (Standart Ketersediaan, Ruang Lingkup dan Penggunaan HAKI), terdiri atas beberapa bagian, antara lain bagian hak cipta dan hak terkait,

\footnotetext{
5 Sanib, S. S. (2019). Ketentuan-ketentuan TRIPS-Plus dalam Kerangka Perjanjian Perdagangan Bebas. Halu Oleo Law Review, 3(1), halaman 51 Dalam Nurul Barizah, Intellectual Property Implications on Biological Resources: Indonesia's Adoption of International Intellectual Property Regimes and the Failure to Adequately Address the Policy Challenges In the Area of Biological Resources, Jakarta: The Nagara Institute, 2010, hlm. 5455

6 Sanib, S. S. (2019). Ketentuan-ketentuan TRIPS-Plus dalam Kerangka Perjanjian Perdagangan Bebas. Halu Oleo Law Review, 3(1), halaman 51 Dalam Achmad Zen Umar Purba Perjanjian TRIPS dan Beberapa Isu Strategis, Badan Penerbit F.H Universitas Indonesia dan Jakarta-Bandung: P.T. Alumni, 2011, hlm. 171.
} 
merek dagang, indikasi geografis, desain industri, paten, desain tata letak sirkuit terpadu, rahasia dagang, dan pengendalian praktik anti-monopoli dalam lisensi kontraktual.

Bagian ketiga tentang Enforcement of Intellectual Property Rights (Penegakan HAKI). Di dalam bagian ketiga terdiri lagi beberapa bagian, antara lain bagian, antara lain ketentuan umum, prosedur penegakan hukum, tindakan sementara, persyaratan khusus terhadap tindakan pembatasan, dan prosedur pidana.

Bagian keempat tentang Acquisition and Maintenance of Intellectual Property Rights And Related Inter-Partes Procedures (Pemeliharaan HAKI terhadap keterkaitan para pihak). Bagian kelima tentang Dispute Prevention and Settlement (Pencegahan dan Penyelesaian Sengketa). Bagian keenam tentang Transitional Arrangements (Ketentuan Peralihan). Bagian ketujuh tentang Institutional Arrangements; Final Provisions Part Vii Institutional Arrangements; Final Provisions (Pengaturan Kelembagaan dan Ketentuan Penutup).

TRIPs ditetapkan dengan tujuan untuk memberikan perlindungan HAKI serta penegakan hukum HAKI supaya karya intelektual tumbuh dan berkembang, serta mendukung inovasi dalam berbagai teknologi di antara negara-negara anggota TRIPs. Selain juga untuk menciptakan kesejahteraan sosial dan ekonomi serta keseimbangan antara hak dan kewajiban antara negara anggota.

\subsection{Pengertian Politik Hukum}

Politik hukum berasal dari istilah hukum Belanda rechtspolitiek, bentukan dari dua kata recht dan politiek. Dalam bahasa Indonesia kata recht berarti hukum. Kata hukum berasal dari bahasa Arab hukm (kata jamaknya ahkam), yang berarti putusan (judgement, verdict, decision), ketetapan (provision), perintah (command), pemerintahan (government), kekuasaan (authority, power), hukuman (sentence) dan lain-lain. Kata kerjanya hakama-yahkumu, berarti memutuskan, mengadili, menetapkan, memerintahkan, memerintah, menghukum, mengendalikan dan lain-lain. Dari asal kata hakama memiliki arti mengendalikan. ${ }^{7}$

Secara terminologi, Pengertian politik hukum secara terminology dikaji dengan dua model pendekatan. Pertama, politik hukum dipahami dengan pendekatan memberikan masing-masing pengertian pada kata "politik" dan "hukum" (divergen), selanjutnya menggabungkan kedua kata "politik" dan "hukum" (konvergen). Kedua, pendekatan yang langsung mengartikan "politik hukum" dalam satu kesatuan sebagai frase dengan pengertian yang utuh. Frase "politik hukum" bermakna lebih luas dari kebijakan hukum, pembentukan hukum dan penegakan hukum. Sebagai frase, pengertian "politik hukum" merupakan keseluruhan aktivitas. ${ }^{8}$

Politik Hukum didefinisikan sebagai legal policy oleh Abdul Hakim Garuda Nusantara, mendefinisikan "politik hukum sebagai legal policy atau kebijakan hukum

\footnotetext{
7 Syaukani, I., \& Thohari, A. A. (2013). Dasar-dasar politik hukum. Jakarta: Raja Grafindo Persada, hlm. 19

8 Rosadi, O. (2012). Studi politik hukum:suatu optik ilmu hukum. Yogyakarta: Thafa Media, hlm. 3.
} 
yang hendak diterapkan atau dilaksanakan secara nasional oleh suatu pemerintahan negara tertentu meliputi: (a) pelaksanaan secara konsisten ketentuan hukum yang telah ada; (b) pembangunan hukum yang berintikan pembaruan atas hukum yang telah ada dan pembuatan hukum-hukum baru; (c) penegasan fungsi lembaga penegak hukum serta pembinaan para anggotanya; dan (d) peningkatan kesadaran hukum masyarakat menurut persepsi elite pengambil kebijakan" ${ }^{9}$

Politik hukum secara sederhana dapat diartikan sebagai kebijakan Negara tentang hukum yang akan diberlakukan atau tidak akan diberlakukan yang bentuknya dapat berupa pembentukan hukum baru atau dapat dikatakan dengan pencabutan dan penggantian hukum lama untuk disesuaikan dengan kebutuhan masyarakat. ${ }^{10}$

Hukum dan politik hidup berdampingan, tidak terpisah. Bentuk hukum pun juga dipengaruhi oleh politik hukum. Philippe Nonet dan Philip Selznick menyebutkan ada tiga model hukum yang dipengaruhi oleh suatu politik hukum dalam suatu negara yaitu hukum represif, hukum responsif dan hukum otonom.

Teori hukum responsif memberikan kemampuan pada institusi hukum untuk mempertimbangkan fakta-fakta sosial yang tumbuh di masyarakat secara lebih menyeluruh dan cerdas dimana hukum tersebut dapat berproses serta diimplementasikan secara wajar. Jawaban atas konsep hukum normatif tersebut merupakan adaptasi yang cukup selektif ke dalam berbagai tuntutan perkembangan yang baru. Kriteria yang dimaksud adalah rule of law yang menjadi cita-cita bukan dimaknai sebagai suatu kelayakan prosedural secara formal, melainkan sebagai reduksi secara progresif menjauhkan dari aspek kesewenangan dalam penyalahgunaan kekuasaan menyimpang dari berbagai aspek kehidupan baik dalam politik, sosial, dan ekonomi. Dapat disimpulkan bahwa teori hukum responsif justru akan memperluas cakupannya terhadap keadilan substantif.

Tatanan hukum yang responsif dibutuhkan untuk perubahan sosial dan keadilan sosial. Kebutuhan ini sesuai dengan semangat fungsional, pragmatis, dan semangat purposif (berorientasikan tujuan), seperti Roscoe Pound, para penganut paham realisme hukum, dan kritikus-kritikus kontemporer. The model of rules karya Dworkin, tidak bisa lagi diharapkan dapat menangani dinamika kebutuhan-kebutuhan sosial di tengah perubahan yang tiada terbatas saat ini. ${ }^{11}$

\subsection{Ratifikasi TRIPs Agreement terhadap Politik Hukum di Indonesia}

Keikutsertaan Indonesia dalam perjanjian internasional tentang HAKI, sebagai bukti bahwa Pemerintah Indonesia serius dalam permasalahan HAKI di Indonesia. Patut kita sadari bahwa pemerintah mendukung sistem perekonomian yang terbuka

${ }_{9}^{9}$ Mahfud M.D., Moh. (2011). Membangun politik hukum menegakkan konstitusi. Jakarta: Rajawali Pers, hlm. 13-14.

10 Mahfud M.D., M. (2007). Politik Hukum Dalam Perda Berbasis Syari'ah. Jurnal Hukum Ius Quia Iustum, 14(1), hlm. 2-3.

11 Tanya, B. L., Simanjuntak, Y. N., \& Hage, M. Y. (2010). Teori hukum: strategi tertib manusia lintas ruang dan generasi. Yogyakarta: Genta Publishing, hlm. 205. 
untuk meningkatkan daya saing tingi di kancah Internasional, sebagai konsekuensi sebagai anggota dari WTO. Disamping juga, Indonesia sebagai negara anggota juga harus konsekuen melaksanakan ketentuan TRIPs Agreement sesuai dengan UndangUndang No. 7 Tahun 1994 tentang pengesahan Agreement Establishing the World Trade Organization (Persetujuan Pembentukan Organisasi Perdagangan Dunia).

Sejak Indonesia menjadi anggota WTO, dan telah meratifikasi beberapa perjanjian internasional seperti Trips Agreement melalui Undang-Undang No. 7 Tahun 1994. Permasalahannya yang akan dikaji dalam paper ini keberhasilan memberikan perlindungan dan penegakan hukum HAKI di Indonesia pasca ratifikasi Trips Agreement. Pelanggaran HAKI semakin hari kualitas dan kuantitasnya semakin meningkat.12 Dalam konteks yang sederhana, berbagai pasar di Indonesia masih terdapat menjual berbagai barang yang tidak orisinil, sehingga hal ini akan berdampak merugikan terhadap hak ekonomi dan hak moral dari pemegang HAKI.

Pasca meratifikasi perjanjian internasional, pemerintah Indonesia sudah mengakomodir peraturan perundang-undangan di Indonesia dan sesuai dengan standar yang sudah ditetapkan dalam TRIPs Agreement. Dengan demikian dari aspek paradigma pun telah berubah, dari yang semula bersifat lokal nasional berubah menjadi bersifat global. Selain aspek paradigma, tentu aspek substansinya juga akan ikut berubah menyesuaikan dengan standart yang telah ditetapkan dalam TRIPs Agremeent. TRIPs Agreement secara umum tidak memberikan aspek-aspek perdagangan dari HAKI, namun Pasal 1.2 TRIPs Agreement menyatakan bahwa HAKI terdiri dari Hak Cipta dan Hak terkait, Merek Dagang, Indikasi Geografis, Desain Industri, Paten, Desain Tata Letak Sirkuit Terpadu, Rahasia Dagang, serta kontrol terhadap praktek persaingan usaha tidak sehat dan perjanjian lisensi.

Dalam Penjelasan Undang-Undang No. 7 Tahun 1994 tentang pengesahan Agreement Establishing the World Trade Organization (Persetujuan Pembentukan Organisasi Perdagangan Dunia) point 4 Putaran Uruguay menjelaskan bahwa hal yang dirundingkan salah satunya tentang Trade Related Aspect of Intellectual Property Rights including Trade in Counterfeit Goods/TRIPs (Aspek-aspek dagang yang terkait dengan Hak Atas Kekayaan Intelektual, termasuk perdagangan barang palsu). Perundingan ini bertujuan untuk: ${ }^{13}$ (a) meningkatkan perlindungan terhadap Hak Atas Kekayaan Intelektual dari produk-produk yang diperdagangkan; (b) menjamin prosedur pelaksanaan Hak Atas Kekayaan Intelektual yang tidak menghambat kegiatan perdagangan; (c) merumuskan aturan serta disiplin mengenai pelaksanaan perlindungan terhadap Hak Atas Kekayaan Intelektual; (d) mengembangkan prinsip, aturan dan mekanisme kerjasama Internasional untuk menangani perdagangan

\footnotetext{
12 Nirwani, N. (2018). Seminar Pelanggaran Kekayaan Intelektual. Dikutip 16 Juli 2021, dari situs web Kantor Wilayah Sulawesi Utara Kementerian Hukum dan HAM https://sulut.kemenkumham.go.id/berita-kanwil/berita-utama/2609-seminar-pelanggaran-kekayaanintelektual

${ }_{13}$ Penjelasan Undang-Undang No. 7 Tahun 1994 tentang pengesahan Agreement Establishing the World Trade Organization (Persetujuan Pembentukan Organisasi Perdagangan Dunia).
} 
barang-barang hasil pemalsuan atau pembajakan atas HAKI. Kesemuanya tetap memperhatikan berbagai upaya yang telah dilakukan oleh World Intellectual Property Organization (WIPO)".

Undang-Undang No. 7 Tahun 1994 secara langsung melindungi kekayaan intelektual yang berasal dari olah pikir atau intelektual tiap individu. Adanya ratifikasi UU tersebut akan menjadi legacy terhadap sistem perlindungan dan penegakan hukum HAKI. Dengan adanya legacy tersebut dapat menekan tingkat pembajakan atau pemalsuan terhadap barang atau jasa yang terdaftar dalam HAKI.

Sistem HAKI di Indonesia menganut sistem first to file, yang artinya bahwa siapa yang mendaftarkan HAKI lebih dahulu akan berhak atas HAKI tersebut. Sebagai contoh sistem first to file berlaku, A memiliki usaha di bidang kuliner yang masih dalam proses pendaftaran merek misalnya, sedangkan B sama-sama memiliki usaha kuliner yang serupa dengan A namun sudah didaftarkan lebih dahulu dan sudah memiliki bukti kepemilikan hak yakni berupa sertifikat. Dengan begitu merek si A akan ditolak karena serupa dengan B yang sudah terdaftar lebih dahulu.

HAKI adalah hak ekslusif yang tumbuh dari rasio daya pikir manusia yang memiliki nilai ekonomi dan nilai moral melekat pada pemegang hak-nya. Di sinilah ciri khas HAKI, setiap orang memiliki hak untuk mendaftarkan hasil intelektualnya atau tidak. Hak eksklusif diberikan negara kepada pemegang kekayaan intelektual sebagai bentuk suatu penghargaan atas hasil karya kreatifitas agar orang lain termotivasi untuk dapat mengembangkannya lagi dari kreatifitas yang sudah ada, sehingga dengan sistem HAKI dalam tersebut kepentingan masyarakat ditentukan melalui mekanisme pasar serta perlindungan yang diberikan negara memberi rasa aman kepada setiap pemilik HAKI.

Dalam proses kesepakatan perjanjian internasional di bidang HAKI, Negara ikut serta mengutus wakilnya karena substansi yang ada di dalamnya tergolong penting dan memiliki bobot yang sangat tinggi. Kewajiban suatu Negara tidak semata-mata lahir karena telah meratifikasi kesepakatan menjadi undang-undang, melainkan lahirnya kewajiban karena subyek hukum (Negara) ikut menyetujui apa yang telah menjadi kesepakatan bersama, dan ini sudah sesuai dengan asas hukum Pacta Sunt Servanda.

Ketika perjanjian internasional diratifikasi melalui undang-undang, maka berimplikasi bahwa perjanjian internasional tersebut telah menjadi hukum nasional, sudah berlaku serta memiliki kekuatan hukum yang mengikat. Dengan demikian pemerintah dan warga negara wajib mentaati dan tunduk pada perjajnjian internasional yang telah menjadi hukum nasional tersebut, kecuali ditentukan lain di dalam peraturan perundang-undangan yang bersangkutan. ${ }^{14}$

Terdapat dua teori yang dapat dipergunakan untuk memahami berlakunya hukum internasional, yaitu teori monisme dan teori dualisme. Teori Monisme

14 Ume, Y. Y. R. S. (2020). Implikasi Proses Ratifikasi Perjanjian Internasional terhadap Hukum Nasional. Lex et societatis, $8(1)$, hlm. 30-31. 
mengatakan bahwa: "hukum internasional dan hukum nasional merupakan dua aspek yang sama". Sementara teori dualisme mengatakan bahwa: "hukum internasional dan hukum nasional berbeda secara intrinsik, baik dalam subjek hukum serta sumber hukum". Hukum nasional memiliki integritas yang jauh lebih sempurna dibandingkan dengan hukum internasional. Transformasi atau perubahan menjadi hukum nasional diperlukan untuk mengadopsi perjanjian internasional ke dalam hukum nasional. Transformasi tersebut hendaknya juga harus disesuaikan dengan legal culture masyarakat hukum Indonesia.

Penggunaan teori hukum responsif erat hubungannya dengan fakta sosial yang berproses dalam penegakan hukum. Menurut Lawrence M. Friedman, bahwa efektif atau tidaknya Penegakan Hukum berdasarkan pada 3 substansi, Struktur Hukum (aparat penegak Hukum), Substansi Hukum (Peraturan perundang-undangan) dan Budaya Hukum (Legal Culture). Ketiga substansi hukum tersebut merupakan instrument pokok dalam mewujudkan penegakan hukum yang berkeadilan terhadap kepentinganmasyarakat. Keterkaitan antar substansi tersebut akan memberikan solusi terhadap setiap peristiwa hukum yang terjadi, sehingga ketiga substansi tersebut tidak terpisahkan. Legal culture dipandang sebagai perilaku sosial yang mempengaruhi kehidupan masyarakat sebagai subyek hukum. Hal tersebut dilihat dari perilaku masyarakat ketika bersentuhan dengan hukum. Baik buruknya perilaku masyarakat hukum akan mempengaruhi pola custom (kebiasaan) yang demikianlah budaya hukum akan tercipta. Budaya hukum yang positif akan memberikan kontribusi yang positif juga bagi kehidupan masyarakat hukum di suatu locus (wilayah) tertentu.

Dalam hal pemaparan terkait HAKI, dari segi substansif, norma hukum yang mengatur tentang HAKI tidak terbatas terhadap norma hukum yang dikeluarkan oleh suatu Negara, melainkan juga terikat terhadap norma-norma hukum Internasional. Pada hakikatnya suatu sistem hukum akan tumbuh dan berkembang mengikuti kemajuan peradaban dunia. ${ }^{15}$ Menurut teori hukum pembangunan, hukum adalah alat untuk memelihara ketertiban masyarakat. Hukum pada dasarnya bersifat konservatif maksudnya adalah bahwa hukum mempunyai sifat memelihara dan mempertahankan yang telah tercapai. Fungsi hukum yang demikian tersebut sangat diperlukan dalam masyarakat, termasuk masyarakat yang sedang membangun. Dalam masyarakat yang sedang membangun, hasil-hasil pembangunan ada yang harus dipelihara, dilindungi dan diamankan. Hukum tidak hanya memiliki fungsi-fungsi memelihara yang telah tercapai dalam konteks masyarakat yang sedang membangun, mengingat masyarakat yang sedang membangun berarti masyarakat yang sedang berubah cepat. Dalam masyarakat yang sedang berubah cepat, maka hukum juga harus dapat membantu proses perubahan masyarakat tersebut. Pandangan yang kolot tentang hukum yang menitikberatkan fungsi pemeliharaan ketertiban dalam arti statis, dan menekankan sifat konservatif dari hukum, menganggap bahwa hukum tidak dapat memainkan

\footnotetext{
15 Saidin. (2006). Aspek Hukum Hak Kekayaan Intelektual. Jakarta: Raja Grafindo Persada, hlm. 23.
} 
suatu peranan yang berarti dalam proses pembaharuan. ${ }^{16}$ Hukum berfungsi sebagai sarana guna memelihara ketertiban masyarakat. Selain itu, hukum membantu proses perubahan masyarakat, sehingga perubahan tersebut dapat berlangsung secara teratur dan tertib. ${ }^{17}$

Implementasi politik hukum HAKI di Indonesia akan memberi energi positif terhadap pembangunan hukum di Indonesia. Termasuk di dalamnya mempertahankan kearifan lokal yang merupakan keunikan atau ke-khas-an etnis tiap daerah. Politik hukum digunakan sebagai wadah untuk menegakkan konstitusi melalui peraturan perundang-undangan tentang HAKI yang diakui oleh hukum nasional.

Pembentukan hukum nasional berpuncak pada Undang-Undang Dasar Republik Indonesia Tahun 1945. Prinsip-prinsip dasar dalam UUD 1945 yang menjunjung tinggi nilai filosofis, yuridis dan sosiologis yang sesuai dengan ruh bagi bangsa Indonesia. Sehingga dalam penegakan hukum harus memperhatikan prinsip Negara hukum. Begitu juga dalam pengaturan HAKI, agreement yang diratifikasi disesuaikan dan tidak bertentangan dengan jiwa bangsa Indonesia.

Penegakan prinsip dasar UUD 1945 terhadap pengaturan HAKI mengalami tantangan yang besar ketika Indonesia menjadi anggota WTO/TRIPs Agreement sejak tahun 1994. Prinsip yang telah diusung dalam WTO/TRIPs Agreement tidak selalu berbanding lurus terhadap prinsip dasar yang terdapat dalam UUD 1945, sebagai contoh. ${ }^{18}$ Pertama, paham individualisme yang menjadi landasan dalam konsep HAKI. Kedua, penerapan prinsip full compliance atau kepatuhan penuh dalam artikel XVI TRIPS Agreement, artinya kesepakatan bersama yang dituangkan dalam agreement tersebut harus dipatuhi secara keseluruhan oleh Negara-negara anggota. Dengan kata lain, full compliance ini tidak mengedepankan hukum nasional tiap Negara anggota, melainkan lebih mengedepankan hukum internasional yang bersifat universal. Ketiga, dalam hal komersialisasi HAKI, hal ini bertujuan untuk mendapatkan keuntungan semaksimal mungkin. Disamping itu, Negara juga memiliki hak melakukan tindakan hukum apabila dirugikan oleh Negara lain mengenai kepentingan HAKI-nya. Tindakan tersebut dapat berupa tindakan pembalasan ataupun tekanan secara ekonomi kepada Negara tertentu yang melanggar kepentingan. Sistem penyelesaian sengketa HAKI antar negara anggota merupakan usaha untuk melaksanakan kepatuhan terhadap TRIPs Agreement, dalam sistem penyelesaian sengketa terpadu membenarkan adanya retaliasi silang (cross retaliation) yang bersifat dalam lingkup lintas sektoral.

16 Kusumaatmaja, M. (2002). Konsep-konsep hukum dalam pembangunan: kumpulan karya tulis. Bandung: Alumni, hlm. 13-14.

17 Aulia, M. Z. (2018). Hukum Pembangunan dari Mochtar Kusumaatmadja: Mengarahkan Pembangunan atau Mengabdi pada Pembangunan? Undang: Jurnal Hukum, 1(2), 363-392. https:/ / doi.org/10.22437/ujh.1.2.363-392, hlm 371.

18 Irawan, C. (2011). Politik hukum hak kekayaan intelektual Indonesia: kritik terhadap WTO/TRIPs agreement dan upaya membangun hukum kekayaan intelektual demi kepentingan nasional. Bandung: Mandar Maju, hlm. 22. 
Perbedaan realitas sosial yang terjadi dalam TRIPS Agreement dan realitas sosial bangsa Indonesia sebagai alasan bahwa masih terdapat Negara maju dan Negara berkembang. Negara maju merupakan pihak yang mengusulkan dimasukkannya HAKI sebagai bagian dari kesepakatan WTO. Alasan yang mendasari adalah kekuatan Iptek yang melatarbelakangi perlindungan yang kuat dan sesuai dengan standart demi keuntungan bidang ekonomi di dunia. Sedangkan di dalam Negara-negara berkembang, perkembangan iptek belum secanggih di Negara maju.

Konsensus yang terjadi antara Pemerintah Indonesia dengan negara-negara lain, organisasi internasional, serta subjek hukum internasional yang lain merupakan perbuatan hukum yang penting karena bersifat mengikat suatu negara dan subjek hukum internasional yang lain. Oleh karena itu, konsensus dalam perjanjian internasional disahkan dan dilakukan sesuai ketentuan undang-undang. ${ }^{19}$

Pembentukan UU dalam HAKI ternyata tidak sepenuhnya karena alasan internal suatu Negara (misalnya pendirian industri), melainkan juga dikarenakan mengikuti atau menyeseuaikan dengan kepentingan-kepentingan asing seperti politik dagang negara maju, serta memperbaiki iklim investasi asing sehingga perlu dilakukan penyesuaian materi UU dengan TRIPs. Kepentingan internal suatu Negara dengan kepentingan asing tersebut akan berpengaruh terhadap berlakunya UU yang akan dibentuk, terlebih lagi jika materi muatan dalam UU dirasa asing oleh masyarakat setempat. ${ }^{20}$

Indonesia sebagai Negara hukum, memiliki hierarki peraturan perundangundangan tertinggi yang berpuncak pada konstitusi. Dapat dipastikan jika ketentuan dalam perjanjian internasional tidak sesuai dengan hukum di Indonesia akan dikembalikan kepada konstitusi. Sebab konstitusi merupakan sumber dari segala sumber hukum yang berlaku. Oleh karena itu implementasi politik hukum di Indonesia harus disesuaikan dengan kehidupan bangsa Indonesia dalam segala aspek. Selain itu, pelaksanaan politik hukum di Indonesia tidak boleh menghadirkan hukum atau peraturan perundang-undangan yang digunakan untuk kepentingan penguasa. Hukum hadir sebagai alat pemersatu, tidak boleh menjamin kepentingan beberapa penguasa melainkan memberi kepastian, keadilan, kemanfaatan dan melindungi segenap bangsa Indonesia.

\section{Kesimpulan}

Agreement Establishing the World Trade Organization telah diratifikasi oleh Indonesia melalui Undang-undang Nomor 7 Tahun 1994 tentang Pengesahan Agreement Establishing the World Trade Organization (Persetujuan Pembentukan Organisasi Perdagangan Dunia). Perlindungan terhadap kepentingan nasional menjadi

\footnotetext{
${ }^{19}$ Hassim, H. (2019). Hubungan Hukum Internasional dan Hukum Nasional Perspektif Teori Monisme dan Teori Dualisme. Mazahibuna: Jurnal Perbandingan Mazhab, 1(2), h1m. 77.

${ }^{20}$ Aulia, M. Z. (2015). Politik Hukum Pembentukan UU Paten di Indonesia: Industrialisasi, Liberalisasi, dan Harmonisasi. Jurnal Hukum Ius Quia Iustum, 22(2), hlm. 235.
} 
tantangan yang harus dihadapi bangsa Indonesia. Sejak bergabung serta ikut dalam perundingan TRIPs, dalam arti Indonesia sepakat terhadap ketentuan yang berlaku, yang tidak semua ketentuannya selaras dengan iklim budaya bangsa Indonesia. Ratifikasi perjanjian internasional dalam bidang HAKI menimbulkan berbagai dampak yang mempengaruhi iklim politik hukum dalam negeri.

Secara konseptual dampak politik hukum terhadap ratifikasi TRIPS Agreement adalah penyelarasan pengaturan sistem HAKI secara global yang bersifat lex generali. Sedangkan penyesuaian di Indonesia disesuaikan dengan hukum nasional yang bersifat lokal sebagai lex specialistnya. Secara implementasi dampak politik hukum ratifikasi TRIPS Agreement akan membawa persaingan bisnis secara global dengan berbagai macam kepentingan berbaur di dalamnya. Ini merupakan konsekuensi dari sifat full compliance yang dianut dalam TRIPs Agreement. Kepatuhan penuh terhadap agreement tersebut bukan berarti mengesampingkan hukum nasional tetapi harus menyesuaikan dengan sitem hukum nasional bukan sebaliknya. Sehingga adopsi agreement ke dalam hukum nasional akan membawa energi positif terhadap berlakunya hukum HAKI di Indonesia.

\section{Daftar Pustaka}

Ali, Z. (2009). Metode penelitian hukum. Jakarta: Sinar Grafika.

Aulia, M. Z. (2015). Politik Hukum Pembentukan UU Paten di Indonesia: Industrialisasi, Liberalisasi, dan Harmonisasi. Jurnal Hukum Ius Quia Iustum, 22(2), 223-237. https:// doi.org/10.20885/iustum.vol22.iss2.art3

Aulia, M. Z. (2018). Hukum Pembangunan dari Mochtar Kusumaatmadja: Mengarahkan Pembangunan atau Mengabdi pada Pembangunan? Undang: Jurnal Hukum, 1(2), 363-392. https:// doi.org/10.22437/ujh.1.2.363-392

Hanafi, I. H. (2011). Perdagangan Internasional Pasca Putaran Uruguay dan Dampaknya di Indonesia. Jurnal Sasi, 17(4), 1-7.

Hassim, H. (2019). Hubungan Hukum Internasional dan Hukum Nasional Perspektif Teori Monisme dan Teori Dualisme. Mazahibuna: Jurnal Perbandingan Mazhab, 1(2), 166-179.

Irawan, C. (2011). Politik hukum hak kekayaan intelektual Indonesia : kritik terhadap WTO/ TRIPs agreement dan upaya membangun hukum kekayaan intelektual demi kepentingan nasional. Bandung: Mandar Maju.

Jamilus. (2017). Analisis Fungsi dan Manfaat WTO bagi Negara Berkembang (Khususnya Indonesia). Jurnal Ilmiah Kebijakan Hukum, 11(2), 205-225.

Kusumaatmaja, M. (2002). Konsep-konsep hukum dalam pembangunan: kumpulan karya tulis. Bandung: Alumni.

Mahfud M.D., M. (2007). Politik Hukum Dalam Perda Berbasis Syari'ah. Jurnal Hukum Ius Quia Iustum, 14(1).

Mahfud M.D., Moh. (2011). Membangun politik hukum menegakkan konstitusi. Jakarta: Rajawali Pers. 
Nirwani, N. (2018). Seminar Pelanggaran Kekayaan Intelektual. Retrieved July 16, 2021, from Kantor Wilayah Sulawesi Utara Kementerian Hukum dan HAM website: https://sulut.kemenkumham.go.id/berita-kanwil/berita-utama/2609seminar-pelanggaran-kekayaan-intelektual

Rosadi, O. (2012). Studi politik hukum:suatu optik ilmu hukum. Yogyakarta: Thafa Media.

Saidin. (2006). Aspek Hukum Hak Kekayaan Intelektual. Jakarta: Raja Grafindo Persada.

Sanib, S. S. (2019). Ketentuan-ketentuan TRIPS-Plus dalam Kerangka Perjanjian Perdagangan Bebas. Halu Oleo Law Review, 3(1), 50-66. https:// doi.org/10.33561/holrev.v3i1.6016

Syaukani, I., \& Thohari, A. A. (2013). Dasar-dasar politik hukum. Jakarta: Raja Grafindo Persada.

Tanya, B. L., Simanjuntak, Y. N., \& Hage, M. Y. (2010). Teori hukum: strategi tertib manusia lintas ruang dan generasi. Yogyakarta: Genta Publishing.

Ume, Y. Y. R. S. (2020). Implikasi Proses Ratifikasi Perjanjian Internasional terhadap Hukum Nasional. Lex et societatis, 8(1). https:/ / doi.org/10.35796/les.v8i1.28468

Peraturan Perundang-undangan

Undang-Undang No. 7 Tahun 1994 tentang pengesahan Agreement Establishing the World Trade Organization (Persetujuan Pembentukan Organisasi Perdagangan Dunia). 